Саша Р. Козић

Средња стручна школа „Милош Црњански”

Кикинда

cunzfra88@gmail.com doi: 10.19090/zjik.2018.61-73

UDK 821.163.41.09 Ninković N.

оригинални научни рад

\title{
ЕЛЕМЕНТИ КАРНЕВАЛИЗАЦИЈЕ И ВИШЕГЛАСЈА У ДЕЛУ НИЋИФОРА НИНКОВИЋА ЖИЗНИОПИСАНИЈА МОЈА
}

САЖЕТАК: У овом раду приступа се мемоарима Нићифора Нинковића с аспекта Бахтинових истраживања. При томе се пажња усмерава на елементе карневализације и вишегласја који се могу пронаћи у делу Жизниописанија моја. Циљ рада је да се истакну хуморни елементи, као и мотив детронизације јунака како би се осветлила чињеница да је реч о писцу који је био испред свог времена.

Кључне речи: мемоарска проза, дијалог, полифоничност, карневализација.

Нићифор Нинковић у свом делу Жизниописанија моја оставио је сведочанство како о својим потуцањима по свету тако и о тиранији владавине кнеза Милоша Обреновића. То је белешка о времену, боље речено амбијенту, који се чини нестварним, уколико се узме у обзир да су Жизниописанија моја мемоари ученог човека који је имао част да буде берберин Милоша Обреновића, и који му је, узгред буди речено, упропастио живот.

Велика дела су често продукт великих мука и злопаћења оних који их пишу. Судбина Нинковића (уколико се за истину узме само половина од онога што је аутор читаоцу исповедио) јесте мучна и тешка. За читање дела важан је контекст времена у ком су Жизниописанија настајала, као и специфичан менталитет (који је и Домановић приказао у својим делима).

С друге стране, треба узети у обзир степен истинитости ових мемоара, уколико се полази од чињенице да су мемоари прозни облик који у себи садржи сећање на одређени период, као и људе који су у њему живели. Нарочито ако се Жизниописанија посматрају као документ који реферише о мрачном периоду српске историје, као и владару ком је био близак писац ових мемоара. Сећање митологизује одређени догађај из прошлости. То је нарочито битно када је реч о тексту који служи за потребе историје и који је ту да посведочи о нечему што је за самог писца било битно, а што је потоњим поколењима желео да пренесе. Аутор у тексту на неколико места позива читаоца да верује у истинитост онога што је написано, односно, наглашава да 
му није намера да себе начини жртвеним јагњетом Милоша Обреновића, већ да покаже какав владар земље не треба да буде и шта све непросвећеност може да узрокује. Ипак, читаоцу је тешко да поверује у исказ аутора да он не жели да буде окарактерисан као колатерална штета Милоша Обреновића будући да текст Жизниописанија на више места приказује Нинковића као жртву, док његова намера да се бави природом владара и власти прелази у други план. Ови мемоари нису само сведочанство о прошлости и протеклом добу него су они кроз процес стварања преточени у уметничко дело, чиме су се из документарне исповедне грађе преместили у књижевну. Отуда Жизниописанија моја треба читати као уметничко дело, које не само да је у односу на дела својих савременика било испред свог времена него је и, по речима Милисава Савића, најављивало „модерни књижевни сензибилитет” (Савић 1988: 402).

Полазећи од чињенице да Жизниописанија моја садрже полифоне и карневалске елементе, овим мемоарима ће се приступити с Бахтинове тачке гледишта, имајући у виду његове студије Проблеми поетике Достојевског и Стваралаштво Франсоа Раблеа и народна култура средњега века и ренесансе. Наравно, овај рад нема намеру да изједначи Нинковићеве мемоаре с делима Достојевског и Раблеа. Међутим, одређене сличности ипак могу да се пронађу, нарочито ако се узму у обзир појмови вишегласја и карневализације. У Нинковићевим мемоарима реч и дијалошка структура текста имају превагу, будући да се аутор исповеда и у разговорима дочарава атмосферу ондашње Србије, при чему је могуће уочити извесне паралеле с делима Достојевског на плану књижевног поступка. С друге стране, језик у Жизниописанију близак је како Раблеовом делу Гаргантуел и Пантагруел, тако и народној култури коју Бахтин објашњава у својој студији посвећеној овом француском писцу (Bahtin 1978).

Поред тога, у раду ћемо се највише ослањати на четврто поглавље Бахтинове студије: Жанровске карактеристике у делима Достојевског и сижејно-композищијске одлике тих дела, како се у Жизниописанијима може наићи на појединости о којима је у том поглављу реч, а које своје порекло воде од Сократових дијалога и менипеја (Менипејевих сатира), који садрже елементе карневалске атмосфере незаобилазне за Бахтинову теорију. При томе, у тексту ће пажња највише бити посвећена дијалошким елементима, исмевању, детронизацији, редукованом смеху, туђој речи, која је полазна тачка Бахтинове теорије дијалога, као и карневализацији у којој се изједначавају 
високо и ниско и где, отуда, нема разлике између људских јединки без обзира на то што их раздваја социјални статус, јер су током карневала, као и у смрти, сви једнаки. На све то надовезаће се вулгарност говора јунака у Нинковићевом делу јер је опсцено својство ових мемоара блиско слободном уличном говору који затичемо у Гаргантуелу и Пантагруелу.

Оно што најпре заокупља пажњу у Жизниописанијима јесте лепршавост језика. Тај језик није комплексан и читаоца увлачи у дијалошки саоднос јер је текст упућен читаоцу као одређена врста исповести писца што је у својим животним путешествијама испио горки талог жучи из пехара Милоша Обреновића. Такав карактер мемоара показује чињеницу да се писац обраћа (исповеда) читаоцу, чиме се наглашава полифонијска структура, како се дијалог активира на два плана. С једне стране, он се у разговору јунака одвија према одређеном току саме речи изречене међу јунацима, а с друге, тај дијалог је упућен и трећем учеснику - читаоцу који то опет из своје перспективе посматра и на себи својствен начин поима, бивајући такође у позицији да с текстом (исповешћу) дијалошки расправља, уколико се читање схвата као комуникација између читаоца и аутора.

Такође, оно што је врло битно за Бахтиново полазиште јесте то да је у Жизниописанијима аутору-јунаку супротстављен, ,један објективни свет - свет других свести равноправних са њим” (Bahtin 2000: 49), пошто је судбина јунака одређена другим (Милошем Обреновићем), омеђена и ограничена жељом и вољом, било самог кнеза, било његових поданика који су попут владаревог свевидећег ока. На томе је заснована опозиција из које происходи сваки облик дијалошке расправе.

Поврх свега, иако је средина ондашње Србије руралног а не градског типа (који се везује за карневалску атмосферу у Бахтиновој студији Стваралаштво Франсоа Раблеа и народна култура средњег века и ренесансе), веза ових мемоара с карневализацијом могла би се пронаћи у смеховним аспектима Жизниописанија који су највише везани за псовке и опсцени вокабулар, односно сам језик као „најбогатији арсенал изражајних средстава комике и исмевања" (Проп 2017: 161). Одређујући облике изражавања народне смеховне културе, Бахтин говори о слободном уличном говору. Наводи да нови типови општења рађају нове форме говорног живота; истиче фамилијарно „ти” које мења форму обраћања и пре свега учеснике разговора приближава једне другима, при чему „слабе говорна етикеција и говорне 
забране, појављују се непристојне речи и изрази и слично" (Bahtin 1974: 24). Најпосле „нови тип карневалско-уличног слободног обраћања одражава се у целом низу појава говорног живота. [...] За слободан улични говор карактеристична је честа употреба псовки, то јест погрдних речи и целих израза, понекад веома дугих и сложених" ( Bahtin 1974: 24).

С друге стране, смеховно овде бива последица детронизације самог аутора и јунака. Треба напоменути да смех и смеховно у Жизниописанијима нису као код Раблеа у вези „са актом плођења, рођењем, обнављањем, плодношћу, изобиљем, јелом и пићем, са земаљском бесмртношћу народа [...] с будућношћу, с новим, с оним што долази" (Bahtin 1978: 111). Смех овде најчешће прати вулгаран речник, а ако се на појединим местима затекну слике које нагињу гротески, то није она врста гротескног које је у вези са материјалним. Не постоји амбивалентност, нити „њихов традиционални садржај [...] оплођење, бременитост, рађање, телесни раст, старост, распадање тела и његово рашчлањивање на делове и томе слично" (Bahtin 1978: 34). Свака веза и поклапање с карневалским елементима само је стицај околности и последица слободног говора.

У односу на Бахтиново становиште да се јунаци Достојевског „ничега не ceћају” (Bahtin 2000: 30-31) и да " они немају биографије у смислу прошлости и до краја доживљеног” (Bahtin 2000: 31), односно да се ликови „сећају само оног из своје прошлости што за њих није престало да буде садашњост и што доживљавају као садашњост: неокајан грех, преступ, неопроштена увреда" (Bahtin 2000: 31); јунак Нићифор (истовремено и приповедач), разликује се по томе што читав текст Жизниописанија пише на основу сећања, које га је обузело када је напустио Србију и по други пут узео да се потуца по свету. Тада је очигледно почео да резимира своју судбину, где се као основни узрок његовог животног пада издваја долазак у Србију, а затим и службовање код кнеза. Овај Бахтинов став о непостојању прошлости за јунаке Достојевског, уколико се његова теорија примењује на неком другом делу, не треба да представља препреку и на њега треба гледати као на факт који је погодовао Бахтиновој анализи која је желела показати да је Достојевски „створио нови вид романескног жанра - полифонијски роман” (Bahtin 2000: 253). Свако дело има своје устројство, своја правила и законе, пошто је свако дело, ако не биће за себе, онда материја која потражује да јој се на одговарајући начин приступи. Такорећи, свака теорија примењена на различитим делима даће различите резултате, чему треба тражити узрок у 
самом писцу, његовом сензибилитету, као и начину на који је писац употребио материју из непосредне стварности и преточио је у уметничку творевину.

Бахтинова студија је на исцрпан начин успела да прикаже полифонијску структуру у делима Достојевског, као и нови романескни жанр, горепоменути полифонијски роман. Међутим, Нинковићева Жизниописанија одређују се као мемоари. С друге стране, сам термин роман је тешко одредити, јер он у себи обједињује различите стилске поступке и форме, а то треба нарочито имати у виду када је у питању модерна књижевност. „Историја модерног романа од Сервантеса наовамо је историја антиромана" (Марић 1998: 261), каже Сретен Марић у есеју поводом Стендаловог Картузијанског манастира у Парми. Уколико роман тежи ка антироману (што и дело Достојевског показује у бројним сегментима), онда он може имати разнолике форме, а материју од које је креиран обликује често и без воље писца, претварајући је у смесу, шаролик спектар пун филозофских расправа, токова свести, исповести, хроника, авантуристичких сижеа итд. У том кључу тумачено Нинковићевићево дело задобија обрисе хибридне форме уз полифонијске и карневализацијске елементе.

„Ако пупчана врпца која спаја јунака с његовим творцем није пресечена, онда пред нама није дело већ лични документ" (Bahtin 2000: 51), закључује Бахтин на једном месту у првом поглављу своје студије, што је очигледно када се узму у обзир Нинковићева Жизниописанија, с тим да је у овом делу, поред уплива личног карактеристичног за мемоарску прозу, и сваки поступак јунака доживео одређену поетизацију која је последица надарености самог писца и његове способности да одређени доживљај (ситуацију) на допадљив начин исприповеда и то кроз обраћање другоме, тј. љубезним читатељима. Нарочито је интересантна позиција приповедача који је владар свог изгубљеног времена и својеврсни свезнајући глас који уме, попут Пруста, да наговести оно што ће се догодити, а што ће читалац и сам разабрати како дело буде одмицало.

Насупрот Нићифору приповедачу, Нићифор јунак Жизниописанија обогатио је српску литерарну баштину једним санчопансовским карактером који не преза од свог господара и који се усуђује да га покуди, и то на тако сочне начине да се у покуду укључују и елементи смеха, исмевања и неизбежних вулгаризама без којих би Жизниописанија била знатно осиромашена. Да нема псовки, лакрдија би била без душе, а стварност 
ондашње Србије, као и судбина Милошевог берберина, не би била трагикомична и гротескна као што је то у Жизниописанијима случај.

Лакрдија, смех, исмевање, вулгаризми, свођење јунака на саставни део карневализације, детронизација ликова итд. само су неки од пропратних елемената карневалске атмосфере која је и у Жизниописанијима присутна, не као пренаглашена нијанса, већ више попут наговештаја око јунака који су у близини кнеза Милоша у несвакидашњем амбијенту. Да је то зачуђујућа средина, читалац уочава још на почетним страницама мемоара, када јунакписац пређе преко границе и из једног, може се рећи, уређеног култивисаног простора дође у простор где владају хаос, буне, битке, примитивизми; средину где „су Србљи дивљи били и свирепи како исто тигри и лафови” (Нинковић 1988: 9) и где „су све луди и бесни војводе који не смишљају на бога и браћу своју, и то нису војводе, но прави разбојници” (Нинковић 1988: 31). То је обећавајућа, плодна средина за карневалску атмосферу, где се одсеца глава за најмању грешку или господареву замерку; где се испредају сплетке и где је и сам Милош Обреновић, док још није стекао моћ, био понижаван и називан „крњом”, чиме је већ у самом уводу писац (да ли са свесном намером, или несвесно) открио тенденцију ка томе да се будући кнез Милош детронизује и исмева, што је у погледу карневализације и карневалске атмосфере неизоставно и врло битно. Сигурно да самом Милошу није било пријатно да (након што је био оптужио Карађорђу Максима да му плати коња који му је у боју излипсао), слуша покуду Карађорђа:

Ене, коекуде, јебем га по души, још није му срамота искати да му Максим ата плати. А што ниси ти, курво, на мејдан изишао као он, па нека под тобом цркне. Гледај му јунака, гледај му човека. Е, браћо, баш би га право било убити сад. Та он је за обрану народа и отечество крв своју проливајући, ата уморио. Ја ако би он погинуо, бил' ти могао њега платити? И ако те чујем једанпут, коекуде, да му за ата споменеш, главу ћу ти одсећи (Нинковић 1988: 14).

Након овог монолога битна је сама констатација приповедача: „Ту остане Милош врло посрамљен" (Нинковић 1988: 14). Овај коментар упућује на детронизацију и претрпљену срамоту историјске личности која се у делу обликовала у књижевног јунака. Поред тога, овај монолог открива и својеврсност вокабулара који је такође битан за дела у којима се наилази на карневализацију. Тачније. то је употреба различитих дијалеката и језичких 
стилова и жаргона који, што се тиче књижевности, своје порекло воде из античке Грчке. Све то је својеврсна вишегласност која је у Жизниописанијима заступљена, што се може уочити и у горепоменутој сцени из поглавља насловљеног: $A$ у оно време тако су Србљи дивљи били и свирепи како исто тигри и лафови. Пасаж у ком је Милош детронизован није догађај којем је Нинковић присуствовао, већ је то својеврстан продукт онога што су му очевици препричали, а што је овај вештином свог пера уобличио у причу. Када Нинковић о томе приповеда, то заправо нису његове речи, већ речи оних који су му препричали тај, за Милоша, немили догађај. Места где се у текст уплиће туђ глас у Жизниописанијима честа су и читалац неретко запада у недоумицу чији глас заправо слуша и ко то говори, да ли Нинковић, или неко други чије се речи посредством приповедача чују.

Вишегласје и преношење туђих речи, примећује се, одлика су и константа ових мемоара код којих су литерарно највреднија места нераздвојна од кнеза Милоша Обреновића и свега онога чега hе се берберин код свог господара тиранина нагледати. Када је Нинковић дошао на службу код кнеза, он о њему ништа лепог није чуо. Штавише, речено му је: „Одсад ћеш код њега чудеса видити што смртни човек није видио!” (Нинковић 1988: 131). Касније се и сам у то уверио током своје службе. Ступање у службу и долазак код кнеза у конак, интензивира карневализацију и карневалску атмосферу, која је до тог тренутка (до упознавања кнеза) тињала. Након сусрета с кнезом карневализација се разбуктава, а „чудеса”, сплетке, поигравања, глупост, анимализам, сабласност, тиранија итд. смењују се из поглавља у поглавље. Такође, битна је и чињеница да се разговор међу јунацима претежно одвија у амбијенту отвореног типа, чаршији (тргу), или у кафанама - дакле, просторима који су битни када је реч о карневализацији и карневалској атмосфери, о којој Бахтин пише у својој студији о Достојевском. То су простори у којима сви струје и где се сви срећу и учествују активно у карневализацији, ту је живот заправо окренут наопачке, ту је све другачије и све одудара од обичног и нормалног начина живота. У тим просторима се одвијају дијалози међу јунацима, или се реализују поједине сцене. Ту су сви једнаки, боље речено, изједначени. Ту се укида „свака дистанца међу људима и ступа на снагу посебна карневалска категорија - слободан фамилијаран контакт међу људима" (Bahtin 2000: 117).

Такав саоднос међу јунацима у Жизниописанијима је очигледан. Кнез Милош се не одваја од јунака, он се изједначава са њима. Он не општи као 
господар са својим поданицима, штавише, он ручава са њима за истом трпезом. Нема разлике између кнеза и берберина до пред његов одлазак из Србије на друго потуцање по свету. Нинковић и кнез једнако расправљају и узајамно се детронизују и изругују; Милош детронизује Нинковића разним увредама, пошалицама и задиркивањима поводом његове супруге, док га Нинковић највише детронизује када му указује на његове грешке у владању, када му беседи о његовом понашању. Битно је што се дијалози између господара и берберина махом одвијају у граничном простору (диванани) предсобљу. Са симболичког аспекта, то је простор на прагу где су бића изједначена. С друге стране, и сам Бахтин запажа као карактеристично за дела Достојевског (што и за Жизниописанија може важити) да учесници карневалске игре у његовим делима увек „стоје на прагу (на прагу живота и смрти, лажи и истине, разума и лудила)" (Bahtin 2000: 140).

Поред живота на прагу који је за ондашњу Србију био посве уобичајен, ови мемоари садрже многе сцене које говоре у прилог карневалској атмосфери. Свакако је упечатљив призор Нинковића и његове супруге када бљују док кочијама путују у Крагујевац код господара, кога још нису ни видели а већ им је од њега мука. Ту су многа одступања од нормалног начина живота. Љубоморна кнежева жена убија његову љубавницу. Кнежева љубавница одмерава потенцијалне будуће љубавнице кнежеве. Присутна су разна понижавања и исмевања народа, гротескне сцене једног мрачног доба, призори који зачуђују, ликови који се издвајају својом екцентричношћу. Међу њима се истиче кнез, као садиста који је вичан свакаквој лакрдији. Тако на једном месту он замењује свој идентитет са Амиџом, који постаје господар; све то у сврху збијања шале са остарелим учитељем који је дошао код кнеза да тражи службу. Ова промена идентитета је такође карактеристична за карневализацију, где може доћи до овог типа инверзије и где је посве уобичајено да се на вредносној лествици смењује ниско са високим и обрнуто. Постоје и друга места која са симболичког апсекта осликавају простор у ком се главни јунак налази. Његов дом није затворен простор и нема ограду. Према свему судећи, он живи у неограђеном простору где може да уђе ко хоће и како хоће, и одвуче са собом берберина пред ноге господару.

Примећује се да су вишегласје и карневализација у Жизниописанијима особени и да, ни у ком случају, нису идентични са вишегласјем и карневализацијом који се уочавају у делима Достојевског, што је посве разумљиво. Већ је било напоменуто да се у овим мемоарима може 
наићи на места где речи упућене читаоцима нису Нинковићеве него туђе, будући да он приповеда о догађајима које су му други усмено пренели, и то је један облик вишегласја у Жизниописанијима. Постоји и други у ком приповедач конструише дијалог у тексту тако да један од учесника истовремено и пита и одговара на питање, што може да буде повод за претпоставку да је одговор сабеседника прећутан, односно да онај ко се у дијалогу поставио ауторитативно није обратио пажњу на тај одговор и да он заправо намеће своју причу, своје ставове и своја убеђења, односно, да одговор другог није прихваћен, без обзира на то што још можда није ни изговорен. Такав дијалог би се могао назвати неравноправним дијалогом и такав дијалог је карактеристичан за примитивне средине, пошто у примитивним срединама превласт над речима нема онај ко поседује истину већ онај ко поседује моћ. Овде би као пример могао послужити следећи одломак:

Одем у конак. Замолим се Паштрмцу да ме претрпе који дан, докле какву кућу нађем. На које Паштрмац: - Божја вера ни по сата! Но одма сели се куд ти драго. Па си дошао мене зар да питаш? Е, јеси ли луд? Јеси! Што је мене стало (Нинковић 1988: 159).

Након питања „Е, јеси ли луд?” (Нинковић 1988: 238) могао би се уметнути Нинковићев одговор: „Нисам”. У Жизниописанијима има велик број места у којима је прећутан одговор који се реализовао у току свести Нинковића, када је овај био већ деценијски удаљен од догађаја о којима је у својим мемоарима писао. Нинковић сигурно није могао да одоли да не одговори сабеседницима у својим списима оно што је прећутао у реалним догађајима. Очигледно је да је он у појединим ситуацијама морао да ћути, уколико је желео да сачува голи живот поред господара тиранина, који би убио и за мање ствари него што су то речи покуде на начин његове владавине и режима. Ту се може укључити и сумња у истинитост онога што је у Жизниописанију написано и питање да ли је Нинковић допустио себи да само у свом делу одговара господару онако како је желео, или је он био нарочит тип дворске луде која је могла све да каже, јер у очима господара има статус будале. Вероватније је да он није могао да одоли свом уметничком пориву и да је у мемоарима градио своје виђење и своју представу света. Вероватније је да он није смео да на оговарања: „Служио [...] књаза Србије, као бербербаша, четири године, па у болести нема једне паре, веће оће и он и његова деца да помру од глади” (Нинковић 1988: 238), одговори: „Хеј, животињо четвороножна и марво без рогова, који не умете истину да говорите! Та ја 
нисам код њега служио, но се код њега мучио" (Нинковић 1988: 238), зато што би могао да себе доведе у опасност да га неко господару тужи и тако доведе у непријатну ситуацију. Зато је овакав дијалог одређени облик тока свести који у себи садржи, како туђе речи тако и одговор Нинковића, који се реализује тек кроз акт писања, и тако ствара својеврсно вишегласје.

Међутим, насупрот овом вишегласју, у Жизниописанијима наилазимо и на елементе менипеје и сократског дијалога, о чијим је карактеристикама Бахтин подробно писао у четвртом поглављу своје студије.

За менипеју су веома карактеристичне сцене скандала, ексцентричног понашања, неумесних говора и испада, у ствари, разна нарушавања општеприхваћеног и уобичајеног тока догађаја, прописаних норми понашања и етикеције, међу њима и говорних. [...] За менипеју је карактеристично широко коришћење уметнутих жанрова: новела, писама, ораторских иступа, симпозиона и др. [...] Најзад, последња одлика менипеје је њен актуелан публицистички тон. То је својеврстан „новинарски” жанр античких времена који је веома интензивно одјекивао на актуелна питања. [...] То је својеврстан „пишчев дневник” који настоји да одгонетне општи дух и тенденцију времена у формирању у коме писац живи (Bahtin 2000: 112-113).

Нешто слично се налази и у Жизниописанију, што је очигледно почев од сцена скандала, неумесних говора, све до писама која се на крају мемоара појављују, као и самог стила и својеврсног пишчевог дневника. Говор који се употребљава у Жизниописанијима разнолик је. Постоји неколико облика: народни, књижевни, турски, грчки, влашки, немачки. Све то увећава мелодичност језика ових мемоара и доприноси самом вишегласју. Осим тога, када се има у виду сократски дијалог, а са њим у вези и смех, исмевање и редуковани смех, ово дело такође показује своје сличности са њим. На многим местима тај смех се не наглашава и не потенцира, али се просто осећа, он се у читаоцу буди као продукт трагикомедије која уме да насмеје, али и забрине, па и растужи, прелије смеховно донкихотовском горчином; и све то с лакоћом језика, кроз технику сказа и игру речима. Можда би овај одломак могао да то покаже:

- Сеци главу, Господару, ако бога знаш!

- А шта је, море, зашто?

- Сеци најпре, Господару, па онда да ти кажем. 
- Ма шта је, море? Кад ти одсечем главу, шта ћеш ми казати после?

- Вади, Господару, курчеве из наши' дупета, ако бога знаш.

- Шта је, море? Какве курчеве?

- Вади, Господару, да нас не јебу данашња пашчад, овако старе, у дупе.

- $\quad$ Ма, који је то, оца му јебем?

- Твој Ђока.

- Ма који Ђока?

- Та твој Ђока писар!

- У мене Ђока писара млого.

- Та Ђока, мој зет.

- Устани! Па тако ми кажи, јебем ти памет луду. Сад знам који је Ђока. [...]

- Ја ћу њему сад дати што је његово, ал' ће он бити опет мој Ђока (Нинковић 1988: 242).

Ни сам кнез не зна који је Ђока у питању. Да ли писар, његов Ђока, или неки сасвим други. Изгледа да се Нинковић играо мало речима, боље речено, хомонимима, што му је користило да текст, са једне стране, начини комичним, а са друге, покаже вокабулар кнеза Србије Милоша Обреновића и његових поданика. Постоје и друга места где се смех не наглашава, већ се сам у тексту производи, што је махом у вези са детронизацијом и исмевањем, било самог кнеза, било Нинковића, било неког другог јунака. У тексту се све, примећује се, међусобно допуњује и осликава атмосферу где царују неморал, сплетке, лудило, тиранија, садизам и томе слично. Сам кнез је тиранин, а свако поређење владара с неком од животиња зачуђујуће је упечатљиво и наглашава примитивизам света у ком су све вредности изврнуте, као и живот људи под владавином српских великаша који су преузели манире Османлија.

За крај се може истаћи да постоји неколико начина на који се могу читати Жизниописанија моја. Првенствено као мемоари, потом као исповест једног руинираног живота, као књижевно дело у који се и фикција уплела, а напослетку и као одређена врста сатире, гротеске о једном народу и владарима, који се ни за двеста година (колико ће ови мемоари ускоро бити стари) нису изменили у својим битним особинама. Овим се Жизниописанија придружују Домановићевим делима, пошто су она, заједно са њима, за ово поднебље, нажалост, свевремена и истинита. Владари се смењују и остају 
тирани, док је народ био и остао поводљива марва. Можда је Нинковић због тога и највише инсистирао на поређењу непросвећеног народа са стоком и зверима, чиме је овим мемоарима придодата димензија алегорије о животињама -људима из једне огромне штале у којој владају вуци који „муче [...] и даве како оћеду” (Нинковић 1988: 279).

Једно је сигурно, вишегласје у мемоарима јесте продукт прича које је Нинковић о кнезу слушао и фиксирао писмом, придодавши им своју патину, као и оно што је он из сопственог угла видео. Што се карневализације тиче, она је у мемоарима више последица мрачног амбијента, него пишчеве намере. Боље речено, ондашње српско поднебље имало је све предиспозиције за отеловљење карневализације и карневалске атмосфере која се обликовала у мемоарима. У свему томе Нинковић је био рецептор који је све то вештином пера забележио, и тако оставио несвакидашњи писани траг, по својим карактеристикама придруживши се књижевним делима која у себи обједињују елементе карневалске атмосфере, што није мала ствар. Заправо и српска књижевност има свог Дон Кихота и Санча Пансу уједињене у Нићифору.

\section{ЛИТЕРАТУРА}

Bahtin, Mihail. 1978. Stvaralaštvo Fransoa Rablea i narodna kultura srednjega veka $i$ renesanse. Beograd: Nolit.

Bahtin, Mihail. 2000. Problemi poetike Dostojevskog. Beograd: Zepter Book World. Марић, Сретен. 1998. Огледи I: O књижевности. Сремски Карловци/ Нови Сад: Издавачка књижарница Зорана Стојановића.

Нинковић, Нићифор 1988. Жизниописанија моја. Београд: Нолит.

Проп, Владимир. 2017. Проблеми комике и смеха. Сремски Карловци/ Нови Сад: Издавачка књижарница Зорана Стојановића.

Савић, Милисав. 1988. „Претеча модерне српске прозе”. Жизниописанија моја. Београд: Нолит, 401-415. 
Saša R. Kozić

ELEMENTS OF CARNIVAL AND POLYPHONY IN NIĆIFOR NINKOVIĆ'S STORY OF $M Y$ LIFE

\section{Summary}

This paper analyzes memoirs by Nićifor Ninković having in mind theories of Mikhail Bakhtin. By that, the attention is given to the elements of carnival and polyphony that can be found in the title Story of my life. Aim of this work is to stress the elements of humor, as well as the motif of subversion of the character in order to show that this author was ahead of his time.

Keywords: memories, dialog, polyphony, carnival. 
